\title{
An Introduction to Conversational Interaction and Second Language Acquisition
}

\author{
Xinqiang Wei, Associate Professor \\ North China University of Water Resources and Electric Power, China \\ E-mail: weixinqiang@ncwu.edu.cn
}

Received: February 20, 2012

Accepted: March 5, 2012

Online Published: June 15, 2012

doi:10.5430/elr.v1n1p111

URL: http://dx.doi.org/10.5430/elr.v1n1p111

\begin{abstract}
This paper introduces the main stream of the interactionist approach to SLA, that is to say, the approach to explaining and exploring how conversational interaction facilitates SLA. It follows the history of research development of interactionists, and, therefore, is divided into the following parts: Linguistic input and conversational interaction, The early version of Interactional Hypothesis, The revised role of conversational interaction, and The implication for second language teaching.
\end{abstract}

Keywords: Conversational interaction, Second language acquisition, Linguistic input

\section{Introduction}

Second language acquisition (SLA) is old in the sense that the assumption has existed for centuries that "the better or more accurately we could describe language; the easier it would be for learners to learn it" (Bardovi-Harlig, 1997:18). Pedagogical innovations since 1960s, like the popularity of audio-lingualism, have moved the focus of SLA from the linguistic analysis of pedagogical grammar and the teacher's presentation of that explicitly knowledge as the central in the classroom to how learners come to acquire a second language (L2) in and out of classrooms (Bardovi-Harlig, 1997). Therefore, the study of how L2 learners acquire a second language received the name of second language acquisition by the middle of 1970s. In this sense, SLA is quite new going back only about 40 years. In spite of that, it has become "a complex discourse" in which different voices play out their parts and in which even the opposing paradigms co-exist (McCarthy, 2001:90). This paper would introduce the main stream of interactionist approach to SLA, that is to say, the approach to explaining and exploring how conversational interaction facilitates SLA. It follows the history of research development of interactionists, and, therefore, is divided into the following parts: Linguistic input and conversational interaction, The early version of Interactional Hypothesis, The revised role of conversational interaction, and The implication for second language teaching.

\section{Linguistic input and conversational interaction}

The fundamental, essential role of input-the language to which L2 learners are exposed-is widely recognized in SLA literature (e.g., Ellis, 1990; Gass, 1997). For example, Stephen Krashen (e.g., 1982, 1985) advocates that comprehensible input is necessary and sufficient for learners to foster an L2 development in his famous Input Hypothesis. Learners' access to comprehensible input and their low "affective filter" will make them acquire an L2. However, his arguments are ambiguous and inconsistent when he attempts to explain what process makes input comprehensible (e.g., Ellis, 1999). Influenced by Krashen, interactionists (e.g., Long, 1981, 1983, 1996) believe comprehensible input is necessary for SLA, but focus on how verbal interaction makes linguistic input comprehensible, in particular on occasions where meaning is negotiated. Such a perspective on SLA originates from Hatch's (1978a, 1978b) two seminal papers on language learning and interaction. By then, conversation was commonly viewed as a platform to practice grammar so as to achieve the learner's communicative use of L2. Instead, she urged researchers to examine how the development of L2 might evolve out of conversation.

Following Hatch, Michael Long has enriched and guided the research all along through his early works (1980, 1981, 1983). Long (1981) investigated the discourse structure between native speakers (NSs) and non-native speakers (NNSs), identifying that interlocutors do avoid and repair impasses in their conversation via adjustments to linguistic form, conversational structure and message content, or all three. Such characteristics of NN-NNS discourse structure occur at the interactional, syntactic, lexical and phonological level and prevail in social discourse of NS-NS (native speaker) NS-NNS (non-native speaker), or even NNS-NNS (Long, 1981; Varonis \& Gass, 1985) 
Further, Long $(1981,1983)$ distinguished input from conversational interaction into modified input and modified interaction. Modified input refers to modifications to the linguistic forms directed at NNS. Theorists (e.g., Long, 1981, 1983; Ellis, 1999) claim modified input may be in the forms of ungrammatical or grammatical through varying devices (e.g., omission of grammatical functors such as articles, copula, simplification, regularization and elaboration). They occur inconsistently in terms of contextual factors of the learner's proficiency, age and others. Modified interaction refers to modifications to the interactional structures of NS-NNS discourse, and they are usually in the form of clarification requests, confirmation checks, repetition, and among others. For example,

The NNS uttered "Um?", indicating that he or she had the difficulty to understand. Receiving the signal of non-understanding, NN repeated the utterance in order for the NNS's comprehension. NNS responded to what NN said once arriving at comprehension (Ten clock?), and finally the NNS recast by saying "Ten o'clock."

Long (1983) claims that modified interaction is observed more consistently in NS-NNS discourse than modified input, and that this type of modification is more important than modified input to explain the role of conversation in SLA. Hence, interactionists, in particular, concern interactional modification - that which has become known as the negotiation of meaning (Pica, 1994a, 1994b; Ellis, 1999). Long (1996) defines negotiation of meaning as involving "denser than usual frequencies of semantically contingent speech of various kinds (i.e., utterances by a competent speaker, such as repetition, extensions, reformulations, rephrasings, expansions and recasts), which immediately follow learner utterances and maintain reference to their meaning" (p.452).Varonis and Gass (1985) develop the routine non-understanding negotiation interaction into a model. It consists of the following (Figure 1):

Trigger $\rightarrow$ indicator $\rightarrow$ response $\rightarrow$ reaction to response

Here "trigger" means the speaker's utterance that caused non-understanding. In the above example, that is "When did you finish?". Interactional moves such as clarification request, confirmation check, and comprehension check, among others, can show the difficulty to understating, and are labeled as indicator (Um? in the above example). Whereas, Pica (1988) revised the above model of negotiation, and prefers "signal" instead of "indicator", which goes like:

Trigger $\rightarrow$ signal $\rightarrow$ response $\rightarrow$ resolution to response

She categorizes the above model as one-signal negotiated interactions, and suggests the extended negotiated interactions:

Trigger $\rightarrow$ signal $\rightarrow$ response $\rightarrow$ signal $\rightarrow$ response to signal $\rightarrow$ resolution to response.

Basing on the early work on conversation discourse, interactional theorists intended to explore the process how negotiation of meaning leads to L2 acquisition. During the process, several theoretical perspectives have come out to explore the conditions for negotiated meaning leading to SLA.

\section{The early version of Interactional Hypothesis}

In order to explain how grammar evolves from conversation, Long $(1981,1983)$ put the early work of conversational interaction into the framework of Krashen' Input Hypothesis (1985), and came out his own early version of Interactional Hypothesis ( $\mathrm{IH})$. Long proposes that conversation facilitates SLA because (1) conversation makes input comprehensible; and (2) comprehension will promote acquisition. Conversation makes input comprehension through modified input and modified interaction (negotiation of meaning) in particular.

As research develops, criticisms occur to Krashen's Input Hypothesis. There are three lines of criticism: 1) the insufficiency of comprehensible input; 2) a lack of clarity and consistency in the claims; and 3) inadequate interpretation of the process of comprehension and acquisition. The first criticism claims that comprehensible input alone is not sufficient for acquisition, and suggests that learners' attention to form (focus on form) is necessary for at least some aspects of language development. Long (1996) provides an extensive review of claims as to the insufficiency of comprehensible input. The studies show that learners who have had ample opportunity for comprehensible input still fail to master many aspects of the target language (Schmidt, 1983; Swain, 1985). Long (1996) stresses that learners need to attend to a task if acquisition is to occur, but the best orientation involves attention to both form and meaning, not to either form or meaning alone.

Secondly, the notion of comprehensible input has been criticized for generally lacking clarity and consistency (Chaudron, 1985; Gass, 1988; White, 1989). For example, White (1989) argues that some structures (e.g., the English passive) are learned by failing to understand the input, and goes on to claim that "the driving factor for grammar change is that input is incomprehensible, rather than comprehensible."(p.98). Gass $(1988,1997)$ suggests that what learners need is comprehended input rather than comprehensible input. Comprehensible input refers to the 
speaker, whereas comprehended refers to the hearer. According to Krashen (1985), learners acquire the target form as they try to comprehend the message which contains unknown target forms.

Thirdly, comprehension does not necessarily lead to acquisition. Faerch and Kasper (1986) question the relationship between input and L2 learning through comprehension. Based on a L1 comprehension model, they suggest that L2 learners apply both top-down and bottom-up processes. As learners attempt to comprehend a message, learners attend to form only if there is a gap. Sharwood-Smith (1986) similarly raises concerns about the process of acquisition through comprehension and suggests that types of input which help learners understand the meaning of the message may not lead the learner to attend to form. These criticisms have led researchers to revise the existing model of second language acquisition within the interactional framework.

\section{The revised role of conversational interaction}

Reviewing studies of conversational interaction, Pica (1994a; 1994b) states that, previously, negotiation was considered a simple way of promoting comprehension, but close examination of empirical data reveals that negotiation also brings opportunities for modification of output and feedback focused on form. The first role that conversational interaction facilitates comprehension has been discussed previously, so the other roles are to be discussed in this part.

Modification of output evolved out of criticism of the Input Hypothesis and was suggested by Swain (1985). Swain $(1985 ; 1991)$ argued the insufficiency of comprehensible input through the evaluation of the achievement of Canadian French immersion students. Although they had enough comprehensible input, immersion students continued to make a wide range of grammatical errors (e.g., verb tenses, prepositional usage). Therefore, Swain $(1985 ; 1993$; 1995) suggests the necessity of comprehensible output in her Output Hypothesis. The Output Hypothesis goes as follows: "even without implicit or explicit feedback provided from an interlocutor about the learners' output, learners may still, on occasion, notice a gap in their own knowledge when they encounter a problem in trying to produce the L2." (Swain \& Lapkin, 1995: 373). In her opinion, learner's modified output during negotiation work can have three functions: (1) promote noticing a gap between "what they want to say and what they can say, leading them to recognize what they do not know, or know partially" (1995: 126); (2) test hypothesis to "experiment with new structures and forms, and expand and exploit their interlanguage resources in creative ways" (Pica et al, 1989); (3) a metalinguisitc function to allow learners to reflect consciously about L2 forms.

Her argument that negotiated interaction provides opportunities for learner output is supported in a few studies (Swain \& Lapkin, 1998; Iwshita, 1993; Pica et at, 1989). Studies indicate that during the process of meaning negotiation, learners do indeed modify their output in response to such conversational moves as clarification request or confirmation checks, though NNS learners overall respond to comprehension problems less likely than NSs in quantity and scope (Pica, 1992). Krashen (1985) rejects the Output Hypothesis on the ground that output is too scarce to make a real contribution to acquisition. Instead, Ellis (1999) argues output may afford qualitative opportunities to notice specific features that are problematic to learners. Long (1996: 448) also sees production as "useful...because it elicits negative input and encourages analysis and grammaticization'; it is 'facilitative, but not necessary".

The third function that negotiation of meaning serves in L2 learning is feedback focused on form. Feedback which indicates incomprehension is sometimes called 'negative input' or 'negative evidence', which refers to "direct or indirect information about what is ungrammatical" in the L2 (Long, 1996: 413). Feedback generated through negotiated interaction can be of two types: preemptive (e.g., grammar rules before an actual error) or reactive. If reactive, it can be explicit (e.g., overt grammar correction) or implicit. The implicit can result from a communication breakdown or from a recast (see the taxonomy as below)

Such negative feedback is assumed to draw a learners' attention to mismatches between input and output, including those features that learners may not notice through comprehensible input alone (Long, 1996; Long \& Robinson 1998). In addition, recasts (that is, in general, reformulation of an interlocutor's erroneous utterances without changing their original meanings) are "potentially of special utility" because they occur when NNSs already know the intended meaning, and thus have attentional space to focus on form either provided in the feedback or to repair their responses (Long, 1996: 429). As explained earlier, such attention to form is supposed to be necessary for certain aspects of SLA. This originates from Schmidt's argument (1990, 1993, 1995).

In a series of papers, Schmidt argues that attention is necessary for learning. His argument for the role of attention first came from his diary study (Schmidt \& Frota, 1986), describing his learning of Portuguese during a five-month stay in Brazil. Those features of the input that were consciously noticed by him led to eventual production. 
Reviewing related literature in L1 and L2, Schmidt (1993) stressed the crucial role of awareness at the level of noticing in SLA, which includes learner's being aware of linguistic forms in input for example. There is also awareness at the level of understanding (e.g., learner's being aware of linguistic forms in input), and it facilitates SLA but is not necessary. He argues "... all learning must be accompanied by awareness" if "attentional threshold for storage in memory and the threshold for conscious awareness could be shown to be the same" (p.209). Here, Awareness refers to subjective experience and commonly equated with consciousness (Schmidt, 1990).

Similarly, Robinson (1995) argues for a critical role of awareness in learning. He defines "noticing" as "detection with awareness and rehearsal in short-term memory" (1995a, p.318). His argument is in line with Schmidt (1990, 1993, 1995): all learning involves conscious awareness. However, Tomlin \& Villa (1994) argue that awareness is not required for learning. They decompose attention into: (a) alertness (general readiness to deal with incoming stimuli); (b) orientation (directing attentional resources to specific stimuli); and (c) detection (the registration of stimuli). The detection is necessary for language learning, which does not require alertness, orientation or awareness. Yet, awareness "plays a potential support role for detection, helping set up the circumstances for detection but it does not necessarily lead to detection itself" (Tomlin \& Villa, 1993: 14). In spite of the argument that to what extent attention contributes to SLA, literatures generally agree the indispensable role of varying degree of attention for registration of input in learners' cognitive.

Considering the development in SLA research, Long (1996) in his so-called updated Interactional Hypothesis summarized the factors for negotiated interaction to contribute to SLA:

...negotiation of meaning, and especially negotiation work that triggers interactional adjustments by the NS or more competent interlocutor, facilitating acquisition because it connects input, internal leaner capacities, particularly selective attention, and output in productive ways. (pp. 451-452)

The new version of IH offers a richer view about how negotiation may facilitate language learning. Negotiation of meaning is not just regarded as enabling learners to obtain comprehensible input (positive evidence) and thus lead to acquisition. Besides, during meaning negotiation, learners can get information about what is ungrammatical, which Long (1996) defines as negative evidence (or negative feedback). Input (positive/negative evidence) generated from negotiation are likely to be noticed by L2 learners as negotiation involves high frequencies of related target items while a problem is resolved. Such a theory manipulates the interplay between comprehension, negotiation, attention, and production, which is also seen in Swain's Output Hypothesis (1985, 1993, 1995).

In short, interactionists see the external environment as a source of linguistic input, and L2 learning as a process which involves interaction between the external linguistic environment and the L2 learner's internal mechanism (e.g., attention). With regard to input of various kinds available in the external environment, interactionists focus on how conversational interaction, in particular involving negotiation of meaning. As to learners' innate capability, they focus on learners' internal attention. Their stance differentiates them from SLA behaviorists or innatists. Behaviorists believe input available in the external environment determines SLA, which ignores the internal processing capability of the learner. In contrast, innatists emphasize the importance of the learner's "black box", only regarding input as "trigger" to activate internal language processing (Lightbown \&Spada, 1999; Cook, 2001).

\section{The implication for second language teaching}

Since SLA has "come of age for a critique to publish his or her theory and its relevance to teaching" (McCarthy, 2001: 68), the interactionist approach to SLA has had a significant influence on pedagogy in L2 classrooms as well.

Their approach to SLA, which combines external and internal factors contributing to L2 development that has been discussed above, has motivated the recently advocated instruction of focus-on-form (FFI) (Long \& Robinson, 1998; Lightbown \& Spada, 1999). FFI instruction is defined as pedagogical effort that is used to draw the learner's attention to language forms either implicitly or explicitly, but within the context of meaning (Lightbown \& Spada, 1999). Based on theoretical and empirical research, this approach is considered to be effective for L2 instruction. Theoretically, it incorporates both Long's (e.g., 1996) Interactional Hypothesis and Schmidt's (1990, 1993, 1995) Noticing Hypothesis (necessity of learners' attention in L2 development) (Long \& Robinson, 1998; Doughty \& Williams, 1998; Lightbown \& Spada, 1999). Empirical classroom studies have found evidence that FFI is more effective than traditional focus-on-formS instruction (grammar focused instruction) or focus-on-meaning instruction (meaning focused instruction) for most learners (see the discussion in Lightbown \& Spada, 1999).

According to Long and Robinson (1998), FFI can occur at two levels in L2 classrooms through communicative interaction. One level of FFI refers to how focal attention resources are allocated in a learners' cognition. That is to say, L2 learners internally attend to language form in communicative interaction in the same way that a native 
speaker pauses to consider the most appropriate way to address a stranger. The other can refer to observable behaviors like providing feedback toward L2 learners' non-target utterances. Feedback is presumed to be an effective form of FFI because it either implicitly or explicitly signals or highlights the linguistic problems in learners' utterances.

Implicit corrective feedback within the cognitive-interactionist framework is called a "recast". The previous discussion has indicated that recasts are presumed to be perceptually salient to draw L2 learners' attention to problematic structures in their utterances. Because they are contingent upon the learner's original meanings, L2 learners can leave their processing space on the language form (Long. 1996); they are more likely to contrast the utterances by themselves and the teacher at the level of linguistic form (Leeman, 2003), or take possible opportunities for modified output (Swain, 1985, 1995). In short, L2 learners are assumed to be more likely to attend to problematic language forms in their utterance after recasts (Long, 1996; Doughty \& Varela, 1998). Thus, recasts can function as corrective feedback. Whether the external focus-on-form in the form of recasts can really make the instructed learner focus on form internally requires support based on empirical data on learner attention.

\section{References}

Bardovi-Harlig, K. (1997). The place of second language acquisition theory in language teacher preparation. In K. Bardovi-Harlig \& B. Hartford (Eds.) Beyond methods: Components of second language teacher education (pp. 18 41). New York: The McGraw Hill Companies.

Cook, V. (2001). Second foreign language learning and teaching ( $3^{\text {rd }}$ ed.). London: Arnold.

Doughty, C., \& Varela, E. (1998). Communicative focus on form. In C. Doughty \& J. Williams (Eds.), Focus on form in classroom second language acquisition (pp.15-41). New York: Cambridge University Press.

Doughty, C., \& Williams, J. (Eds.). (1998). Focus on form in classroom second language acquisition. New York: Cambridge University Press.

Ellis, R. (1990). Instructed second language acquisition: learning in the classroom. Oxford: Basil Blackwell.

Ellis, R. (1994). The study of second language acquisition. Oxford: Oxford University Press.

Ellis, R. (1999). Learning a second language through interaction. Amsterdam, Philadelphia : J. Benjamins

Gass, S. M. (1988). Integrating research areas: A framework for second language studies. Applied Linguistics, 9, 92-106. http://dx.doi.org/10.1093/applin/9.2.198

Gass, S. M. (1997). Input, interaction and the second language learner. New Jersey: Lawrence Erlbaum Associates, Inc.

Hatch, E. (1978a). Discourse analysis and second language acquisition. In E Hatch (Ed.), Second Language Acquisition (pp.402-435). Rowley, MA: Newbury House.

Hatch, E. (1978b). Acqusition of syntax in a second language. In J. Richards (Ed.), Understanding second and foreign language learning (pp.34-70). Rowley, MA: Newbury House.

Iwashita , N. (2003). Negative feedback and positive evidence in task-based interaction: Differential effects on L2 development. Studies in Second Language Acquisition, 25, 1-36. http://dx.doi.org/10.1017/S0272263103000019

Krashen, S. (1982). Principles and practice in second language acquisition. Oxford: Pergamon.

Krashen, S. (1985). The input Hypothesis. London: Longman.

Leeman, J. (2003). Recasts and second language development: Beyond negative

evidence. Studies in Second Language Acquisition, 25, 37-63.

Lightbown, P. M., \& Spada, N. (1999). How languages are learned. Oxford: Oxford University Press.

Long, M. H. (1981). Input, interaction, second-language acquisition. In H. Winitz (Ed.), Native language and foreign language acquisition (pp.259-278). New York: New York Academy of Sciences.

Long, M. H. (1983). Native speaker/non-native speaker conversation and the negotiation of comprehensible input. Applied Linguistics, 4, 126-141. http://dx.doi.org/10.1093/applin/4.2.126

Long, M. H. (1996). The role of the linguistic environment in second language

acquisition. In W. Ritchie \& T. Bhatia (Eds.), Handbook of Second Language Acquisition (pp.413-468). San Diego, CA: Academic Press Inc. 
Long, M., \& Robinson, P. (1998). Focus on form: Theory, research and practice. In C. Doughty \& J. Williams (Eds.), Focus on form in classroom second language acquisition (pp.15-41). New York: Cambridge University Press.

McCarthy, M. (2001). Language acquisition: methods and metaphors. In M. McCarthy (Ed.), Issues in applied linguistics (pp. 68-91). Cambridge: Cambridge University Press.

Pica, T. (1988). Interlanguage adjustments as an outcome of NS-NNS negotiated interaction. Language learning, 38, 45-73. http://dx.doi.org/10.1111/j.1467-1770.1988.tb00401.x

Pica, T. (1992). Communication with second language learners: What does it reveal about the social and linguistic process of second language learning? In J. Alatis (Eds.), Georgetown University Round Table on Languages and Linguistics (pp.435-464). Washington, DC: Georgetown University Press.

Pica, T. (1994a). Questions from the language classroom: Research perspectives. TESOL Quarterly, 28, 49-79. http://dx.doi.org/10.2307/3587198

Pica, T. (1994b). Research on negotiation: What does it reveal about second language learning condition, process, and outcomes? Modern Language Journal, 86, 1-19. http://dx.doi.org/10.1111/1540-4781.00133

Pica, T., Holliday, L., Lewis, N. E., \& Morgenthaler, L. (1989). Comprehensible output as an outcome of linguistic demands on the learner. Studies in Second Language Acquisition, 11, 63-90. http://dx.doi.org/10.1017/S027226310000783X

Robinson, P. (1995). Review article: Attention, memory and the 'noticing' hypothesis. Language Learning, 45, 283-331. http://dx.doi.org/10.1111/j.1467-1770.1995.tb00441.x

Schmidt, R. W. (1990). The role of consciousness in second language learning. Applied Lingusitics, 11, 129-158. http://dx.doi.org/10.1093/applin/11.2.129

Schmidt, R. W. (1993). Awareness and second language acquisition. Annual Review of Applied Linguistics, 13, 206-226. http://dx.doi.org/10.1017/S0267190500002476

Schmidt, R. W. (1995). Consciousness and foreign language learning: A tutorial on the role of attention and awareness in learning. In R. W. Schmidt (Ed.), Attention and awareness in foreign language learning (pp.1-63). Honolulu, Hawai'i: University of Hawai'i.

Schmidt, R. W., \& Frota, S. (1986). Developing basic conversational ability in a second language: A cases study of an adult learner of Portuguese. In R. R. Day (Ed.), Talking to learn: Conversation in second language acquisition (pp. 237-326). Rowley, MA: Newbury House.

Swain, M. (1985). Communicative competence: Some roles of comprehensible input and comprehensible output in its development. In S. M. Gass \& C. Madden (Eds.), Input in second language acquisition (pp.235-253). Rowley, MA: Newbury House.

Swain, M. (1995). Three functions of output in second language learning. In G. Cook \& B. Seidlhofer (Eds.), Principles and practice in applied linguistics: Studies in honor of H. G. Widdowson (pp.125-144). Oxford: Oxford University Press.

Swain, M., \& Lapkin, S. (1995). Problems in output and the cognitive processes they generate: A step towards second language learning. Applied Linguistics, 16(3), 371-391. http://dx.doi.org/10.1093/applin/16.3.371

Tomlin, R. S., \& Villa, V. (1994). Attention in cognitive science and second language acquisition. Studies in Second Language Acquistion, 16, 183-203. http://dx.doi.org/10.1017/S0272263100012870

Varonis, E., \& Gass, S. M. (1985). Non-native/non-native conversations: A model for the negotiation of meaning. Applied Linguistics, 6, 71-90. http://dx.doi.org/10.1093/applin/6.1.71

White, L. (1989). Universal grammar and second language acquisition. Amsterdam: Benjamins. 
$\mathrm{NN}$ :

NNS:

NN:

NNS:

NN:

NNS:

When did you finish?
Um?
When did you finish?
Ten clock?
Ten o'clock.
Yeah.

When did you finish?

When did you finish?

Ten clock?

Yeah.

Trigger

Indicator (Signal)

Response

Reaction to response

Figure 1. (Long, 1983)

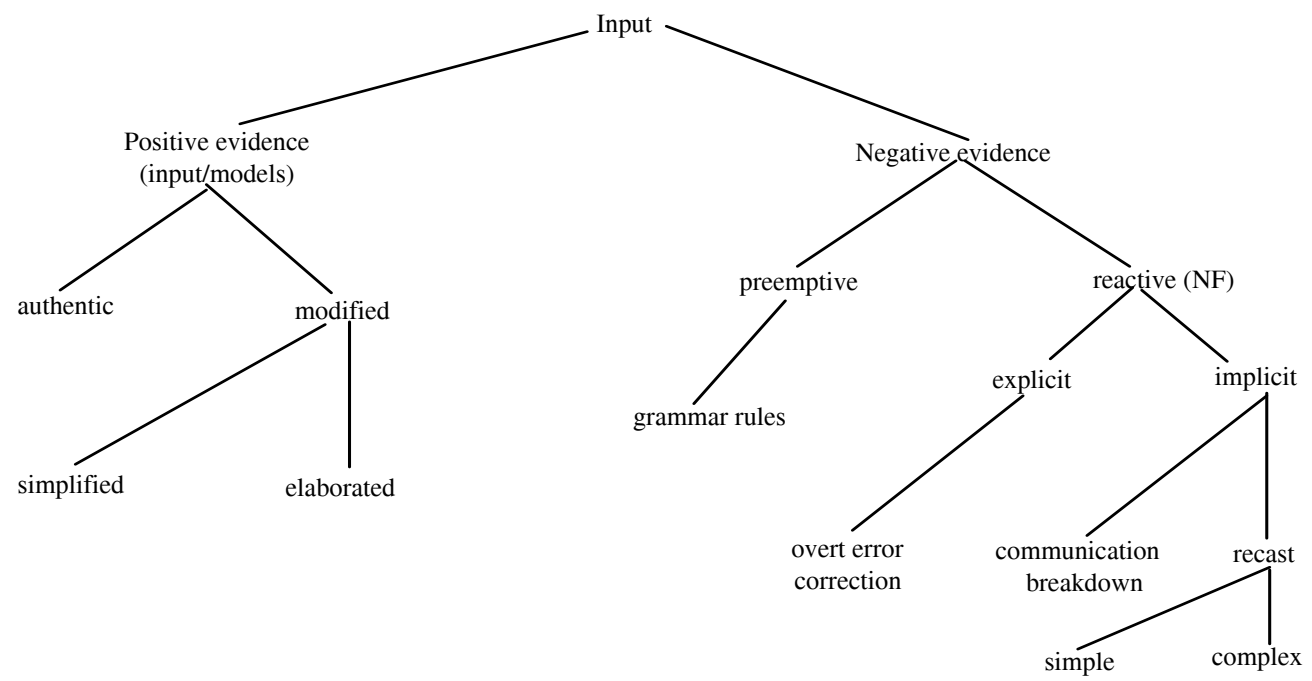

Figure 2. (Long \& Robinson, 1998, p.19) 